\title{
Epitome of Media Education with the Educational Process and its Impact on Developing Students'overall Knowledge
}

\author{
Nazyktere Hasani \\ PhD., Lecturer, Departament of Social Sciences, Faculty of Social Sciences, AAB College, Prishtina, Kosovo
}

MA. Zija Rexhepi

Lecturer, Faculty of Mass Communication, AAB College, Prishtina, Kosovo

\begin{abstract}
The work itself embodies a conceptual highlight of the new approach of the global education, which is the epitome of media education with the educational process. Media education is an indispensable need and an inevitable requirement of global education with a particular role in the development of students' overall knowledge and skills, in particular the creation of a new educational culture and the creation of shared values. The media education at the time of the rapid changes in the field of global education, occupies a special place in achieving qualitative and effective education. The purpose of this paper is to get acquainted with the basic concepts of media education, the possibility of the epitome of media education with educational content during the educational process, the role and effects of this education with the aim of informing relevant school stakeholders on the importance of integrating this education towards the improvement of quality in education.
\end{abstract}

Keywords: epitome of media education, teaching content, the impact of media education on knowledge development.

\section{Introduction}

Global education as an overall process of learning, with a purposeful and lasting impact poses many demands, one of which is that schools have a new developmental approach to learning, in addition to the changes of global society. This new learning approach would enable learners to develop and improve their individual skills, creativity, critical thinking, and cultivate knowledge which they could use throughout their lives.

Schools as educational institutions would play an even greater role in developing and educating young people, in training them in different fields in every aspect of school life by creating and offering numerous opportunities for a quality and effective education with a new approach to education such as media education

Integration, respectively the application of media education during the teaching process, with its educational effects would serve for a better cognitive development of the students, in forming social attitudes and common values by preparing them as active and competitive citizens, with a media culture in the society of knowledge.

\section{The conceptual framework of media education and its purpose}

Media education is a process which in its course includes a new approach of learning towards the intellectual and holistic development of students.

Numerous authors have defined media education as an education that leads students to learn how to act, think critically, and develop their creative abilities and skills necessary for life.

The four main points which media education relies on and which make it special are:

1) The knowledge about media (informative aspect);

2) The use of media (in an interactive way);

3) Personal creativity in the media (aesthetics, creation);

4) Critics of media (reflexive, analytical, ethical, anlaysis etc.) (Musai,2011: 3): 
A large number of authors and theorists have provided numerous definitions regarding media education and its positive effects on intellectual development and preparing young people for active citizenship. Thus, author Bardhyl Musai and his collaborators have defined media education as an approach to media culture which "... is defined as the ability to approach, analyze, evaluate and produce communication in a variety of forms. It is similar to information literacy and includes many components of technological literacy" He further states that "Media education leads children towards the valueof the higher culture, to better forms of behavior or to more rational and politically correct beliefs." (Musai, 2011: 53-69).

Another definition drawn from the research by" Media, Reform Centar, Niš " is that media education teaches how to think, value, act, not just what to think, but emphasizes methods such as critical thinking , solving the stimulation and logical thinking. (Media \&Reform, 2016:5)

Alsothe UNESCO definition of 1982 in the Paris Agenda for Education is that" Media education contributes to people's empowerment and a shared sense of responsibility in society and as such is part of citizenship and human rights education"

Also the researcher Tolić in her research "Temeljni pojmovi suvremene medijske pedagogije" has given the definition of media education according to which "Media education means " think + act" critically ............. "Media education is not only a study, but also a research, taking a critical attitude in achieving the ultimate goals of media competences" (Tolić, 2009:101-102).

Therefore, media education today is dedicated to children from preschool to adulthood, where the demand of global society is to prepare young people for life. This education represents one of the most important and indispensable factors of achievement of a quality education with special features of contemporary education.

\section{Definitions of education purposes}

The purpose of this paper is to get acquainted with the basic concepts of media education, the possibility of embedding media education with learning content during the educational process, the role and effects of this education with the aim of informing relevant school factors on the importance of integrating this education towards the improvement of quality in education. Numerous scholars from this field in their research have clearly defined the purpose of Media education, Musai, 2011 states that the media goal "aims to help students develop the thinking and expression skills needed to be critical thinkers, effective communicators and active citizens of today's society."(Musai,2011:53). It further emphasizes that "The purpose of media education is to prepare children to understand and actively participate in the media culture that surrounds them. The emphasis is on critical comprehension and analysis, which are based on students' critical and creative thinking habits" (Musai,2011: 69). One of the goals of media education is to empower young people to be potential candidates in the labor market.

The research made on media writing by Media \& Reform Centar at the University of Nišs, Faculty of Philosophy states that "The purpose of media education is to change the perception of the meaning and purpose of education and how it is implemented. Education is not just about transferring knowledge, education is about applying the acquired knowledge, experiencing it, it is wisdom, and only then it does make sense" (Media \& Reform, $2016: 4$ ). Also the author of the research "Media Education in Kindergarten", Zorica Petrović clearly states that "The fundamental purpose of media education is to achieve media competence" ... "the important purpose of media education is to build an active and creative relationship in children towards the media" (Petrović, 2011:387,392).

From the above described we can say that the purpose of media education is to create a genuine media culture and mentality in the student's mind and activity that would enable students to become active citizens with professional competences, which means their full development.

\section{The possibility of encapsulating media education with teaching content during the educational process}

Teachers, respectively educators are the key factors in incorporating the concepts of media education into the learning content and their realization during the teaching process. Teachers are the pearls of building and acquiring the knowledge, collaborative skills and skills needed for a successful life. There are many dilemmas that we face. One of them is how we can successfully accomplish a teaching content encapsulating in media education. Author Musa and his collaborators have provided 12 guidelines on how teachers should act to implement this new approach during the teaching process. Let us just list two of them (Musai, 2011:54- 55) : 
1. Practice general observation, critical thinking, analysis, a certain point of view and communication habits. This will be achieved:

By teaching students to ask questions that help them think critically about the information presented to the media (including information in the most viewed books or media at home).

\section{Stir up interest in a new topic. This will be achieved:}

By encouraging students to search the media for information about a topic. Usingshort videos, magazine illustrations, and short articles stimulating a discussion and encouraging students to discuss what they know and express their opinions on the topic under discussion" (Musai,2011:54-55).

Therefore, the educator, respectively the teacher, plays a special role in creating a special place of media education during the teaching process. Teachers are the key factors in changing teaching content and applying new approaches when organizing and leading the educational process. The teacher is required to make changes in the educational work plan and program, the way they are approached, bringing innovation during the education process. So encourage students to think independently, to be actively participe in the learning process, to develop their personal skills, to acquire the skills necessary for life, and to be encouraged to benefit from the experiences in the implementation of media education.

\section{The Role and Effects of Incorporating Media Education in Learning Content}

It is clearly stated that media education enables students to build their knowledge and develop their social skills necessary for life. Media education, on the other hand, is thought to play a special role in the intellectual development, students' thinking skills, and overall development of students, in view of the development and advancement of the society of knowledge.

The effect of epitome of media education with learning content during the teaching process is obvious in learning, activities and its application during the teaching process. Therefore, author Zelembrz, 2018 in her paper cites that authors "Matijević i Topolovčan, 2017"emphasize that digital media during the teaching process enables:

- Individualization of work,

- $\quad$ situational learning (conceptual)

- learning by research

- learning how to solve problems,

- collaborative learning

- learning through games

- $\quad$ project learning

(Matijević i Topolovčan,2017 cited by Zelembrz,2018:7).

Also Mesaroš Živkov, A and her collaborators, 2019 point out that "new media is the support of children in the learning process in a new way; through problem solving, research approaches, finding and memorizing information, till the explicit research of their ideas, propositions and opinions"( Mesaroš Živkov,2018:33).

Certainlythe effects of epitome of media education with the learning content during the teaching process are numerous. Thusmedia education has its positive effect on many aspects of cognitive, intellectual, physical and social developmental skills. In the cognitive aspect we are concerned with the construction, acquisition and development of knowledge, with critical and logical thinking by actively participating and enhancing students' awareness of the importance of mediating writing, where among other things "mediating writing teaches us with the skills we need to navigate the sea of images and messages in everyday life" (Media \&Reform, 2016:5).

The positive effect is also seen in the social aspect where students are raised in their motivation and awareness for social improvement and social cooperation in the development of social skills, collaborative work in solving the problems that have been set, encouragement of creativity that directly affects in their social development. The effects of media education can also appear on students' motivation for collaborative work, stimulation for creative activity, and active learning.

The epitome of media education with teaching content is today considered as one of the opportunities for the development and advancement of contemporary education. 


\section{Conclusion}

From the literature review, it has been noted that the epitome of media education in the teaching process is more than necessary because of its role and effect in educating students through which they build and acquire the necessary knowledge and skills. A well prepared and organized media content teaching would have a significant impact on student preparation and knowledge acquisition for real life implementation, which contributes to the proper functioning of teaching and learning.

It is therefore necessary to raise awareness of relevant school factors on the inclusion of media education in teaching content and its application during the teaching process. So teachers need to be promoted in a continuous professional development in order to respond to the demands of the global society for contemporary teaching that offers numerous creative opportunities, freedom of expression and problem solving, various intellectual activities, improvement of the teacher-student relationship, which results in their continued motivation and interest in working together.

Practicing media education in Kosovo schools is more than necessary, so this paper will be a major contribution to raising awareness of relevant education factors to incorporate media education in schools and promoting it in Kosovo society.

\section{References}

[1] Antolčić, M, (2016) Uloga medija u slobodnom vremenu djece i mladih. Diplomski rad. Sveučilište u Zagrebu.Učiteljski fakultet,Zagreb.

[2] Arsenijević, J. i Andevski, M. (2011). Kompetencije vaspitača za upotrebu novih medija i tehnologija. Zbornik VŠSSOV Kikinda, 2, 25-34.

[3] AufderheideP.,Medialiteracy:From areport of the national leadership,in:Childrentalkingtelevision:ThemakingofTelevisonLiteracy,eds.BuckinghamD.,London1993.CriticosC.,MediaeducationforacriticalcitizenryinSouthAfrica,in:Medialiteracyintheinformationage,eds.KubeyR.,NewBrunswick,NJ1997,str.229240.

[4] Borovica, T. i Kostović, S. (2011) Savremeni mediji u funkciji obrazovne revolucije. Kultura, 137, 370 - 381

[5] Đukić, M. (2003). Didaktičke inovacije kao izazov i kao izbor. Novi Sad: Savez pedagoških društava Vojvodine.

[6] https://seenpm.org/wp-content/uploads/Istrazivanje-MEDIJSKA-PISMENOST-MRCN.pdf see 20.2.2020

[7] https://www.diplomatie.gouv.fr/IMG/pdf/Parisagendafin_en.pdf 2/6/2020 see

[8] J. Maksimović i Z. Stanisavljević Petrović. (2014). Teorijsko-metodološka zasnovanost istraživanja utjecaja medija na adolescente In Medias Res Časopis Filozofije Medija. Vol 3, br. 4, 2014. (472486)

[9] Kačapor, S. (1999): Uvod u školsku pedagogiju. Beograd: Zavod za udžbenike i nastavna sredstva

[10] Korać, N. (1992).Vizuelni mediji i saznajni razvoj deteta,Beograd1992.

[11] Kunczik, M., Zipfel, A. (2006). Uvod u znanost o medijima i komunikologiju. Zagreb: Zaklada Friedrich Ebert.

[12] Lipovac, V. (2003). Didaktički aspekti multimedijalne nastave. Norma, 9(2-3), 211-222.

[13] Livingstone,S.i Bovill,M.(2001).Childrenandtheirchangingmediaenvironment:AEuropeancomparativestudy,LawrenceErlbaum,Mahwah,NJ 2001

[14] Matijević, M., Topolovčan, T. (2017). Multimedijska didaktika. Zagreb: Školska knjiga.

[15] Musai,B, Godole,J ,Abdurrahmani,T.(2011). Edukimi mediatik. Botues: Instituti Shqiptar i MediasTiranë

[16] Petrovič ,Z. ( 2011).Medijsko vaspitanje u vrtiču. Univerzitet u Nišu, Filozofski fakultet - Departman za pedagogiju, Niš

[17] Stanisavljević Petrović, Z. (2011): Medijsko vaspitanje u vrtiću. Kultura, 133, 382-397

[18] Stanisavljević Petrović, Z., Pavlović, D. (2017). Novi mediji u ranom obrazovanju. Niš: Filozofski fakultet.

[19] Stanisavljević Petrović, Z., Radović, V. i Ivanović, A. (2011): Medijska pismenost i kultura učenika osnovnih škola u Nišu. Kultura, 137 210-234

[20] Stanisavljević Petrović-Z (2009).Uloga nastavnika i primena obrazovne tehnologije u školi,u:Tehnologija,informatika,obrazovanje za društvo učenja iznanja(5),priredili Danilović,M.iPopov,Novi Sad.Beograd.

[21] Vasilijević, D., Bojović, Ž. i llić, M. (2015). Primena tehničkih uređaja u radu sa decom predškolskog uzrasta. Zbornik radova, broj 17, str. 53-66. Užice: Učiteljski fakultet. 
[22] Veličković, S. (2014). Edukacija vaspitača za primenu IKT u vrtiću. U: Sinteza - Impact of the Internet on Business Activities in Serbia and Worldwide (pp.375-378). Belgrade: Singidunum University. Doi: 10.15308/sinteza-2014.

[23] Vilotijević, M. (2003). Od tradicionalne ka informacionoj didaktici. Obrazovna tehnologija. 1-2, 15-19

[24] Vlahović, B. i sar. (1996): Opšta pedagogija (red N. Potkonjak). Beograd: Učiteljski fakultet

[25] Zelembrz,T .(2018). Uloga medija u odgoju i obrazovanju Završni rad. Filozofski fakultet, Osijek,Odsjek za pedagogiju.Osijek

[26] Živkov-Mesaroš, A, Karanović-Mićević, J,Pavlov, S, Brkljač, (2019).Digitalni mediji I didaktičke inovacije u radu vaspitača.Pedagoška stvarnost LXV,1(2019),Novi Sad. 